\title{
Cooperative Integrated Reading and Composition (CIRC) Technique in Writing Subject of EFL Context
}

\author{
Zia Hisni Mubarak \\ English Department \\ UniversitasPuteraBatam \\ Batam, Indonesia \\ mubarakzia@gmail.com
}

\author{
Gaguk Rudianto \\ English Department \\ UniversitasPuteraBatam \\ Batam, Indonesia \\ gagukrudianto@gmail.com
}

\begin{abstract}
This research is based on the teaching experience of EFL students in Batam where almost of them are workers from industrial sector. They have little time to read the material and study for the subject since they have to manage their time for both studying and working. By seeing the fact, the researchers are interested to apply one technique that seems appropriate to help the students improve their writing ability called CIRC (Cooperative Integrative Reading and Composition). The purpose of this research is to solve the problems faced by lecturers who teach English especially writing-based subjects in universities in Batam. CIRC is a type of cooperative learning techniques that is expected to provide smart solution for English language learning in university especially among the students-workers type. The research applied the qualitative research by using observation sheet, field notes, and questionnaire. The results showed a good result of using CIRC technique in teaching the writing subject. The finding showed good improvement for both reading and writing where the students' reading were better because they had to read before discussion and they had to discussed how to write the information from their reading into some paragraphs. Thus, CIRC was seen as a good technique for students-workers type where in this technique the students were asked to read and compose about the material given in a small heterogenic group.
\end{abstract}

Keywords-EFL Students, Students-worker, CIRC technique.

\section{INTRODUCTION}

Teaching writing to the students where English is a foreign language (EFL) is not easy. In writing, the rules of writing a paragraph require a comprehensive mastering on the grammar. Students need to have a good understanding on grammar in order to write good and correct sentences. But, mostly students in EFL countries where English is a foreign language, they find some difficulties such as how to arrange the sentence word by word following the grammar and also they have lack of ideas about what to write into their paragraphs. As the result, they did not know how to start their writing. It is acceptable that they assumed writing is the most difficult skill.

Writing as the most difficult skill had been stated previously by Richards and Renandya (2002). The context was for students in ESL (English is a second language) or L2 learners. It is also believed that the students from native speaker context found writing as difficult skill to be mastered. Writing as a skill needs reading to comprehend the information. Students who had problem such as lack of ideas would get ideas for their writing through reading. The reading skill is needed to enhance the students' idea broadly. These two skills are closed and related to each other. Through the reading, the students gain their powerful ideas and some background knowledge related to their writing topic. It is believed that teaching writing with reading is an appropriate way to get students' writing better.

The teaching of writing for the students in EFL context such Indonesia especially in Batam is not enough by using the conventional teaching only. It needs some creative techniques to get the students involved in learning process. One model of learning that is widely known is Cooperative Learning. Cooperative learning is one model that is used widely for teaching students around the world, whether the country is native English or non-native English such Indonesia. Cooperative learning refers to work done by student teams producing a product of some sort such as a set of problem solutions, a laboratory or project report, or the design of a product or a process, under conditions that satisfy five criteria.Felder and Brentagree to the Johnson, Johnson, and Smith theory where they proposed those criteria such as: (1) positive interdependence, (2) individual accountability, (3) face-to face interaction for at least part of the work, (4) appropriate use of interpersonal skills, and (5) group processing(Felder $\&$ Brent, 2007). Thus, in cooperative learning students learn together in a group consisting of two to four students (Jacobs \& Hall, 2002).

The cooperative learning has some techniques to conduct the learning process for instance Students Teams-Achievement Divisions (STAD), Teams-Games Tournament (TGT), Jigsaw, Team Accelerated Instruction (TAI) and Cooperative Integrated Reading and Composition (CIRC). One technique that seemed to be appropriate to teach writing through reading is CIRC technique or Cooperative Integrated Reading and Composition which is developed by Stevans, Madden, Slavin and Farnish. Cooperative integrated reading and composition (CIRC) technique, one of the learning techniques based on cooperation, is designed to develop reading, writing and other language skills in the upper grades of primary education. CIRC technique presents 
a structure that increases not only opportunities for direct teaching in reading and writing but also applicability of composition writing techniques.

To know the writing itself, this research is related to the theories of some experts. A kind of writing for college or university students is called as academic writing where students are prepared to write their thesis (Oshima \& Hogue, 2009). They argue that academic writing is different from other kinds of writing in several ways. For instance, personal writing, literary writing, journalistic writing, business writing, etc. In addition, students in the university or graduate level are facing various writing tasks of academic writing related to their field and their chosen degree (Swales \& Feak, 2004).

Writing is also known as an activity when the writers bring their ideas from mind and change them into topics. The writer draws on background knowledge and complex mental processes in developing new insights (O’Malley \& Pierce, 1996). Another opinion from the scholar defines writing into some definitions. Firstly, "a system of recording language by means of visible or tactile marks". She defines also others definitions such as writing is "the activity of putting such a system to use, the result of such activity, a text, the particular form of such a result; a script style such as block letter writing, artistic composition and a professional occupation"(Coulmas, 2003: 1). From those various definitions of writing, she reflects on the first definition as her major definition of writing.

To write an academic writing is not as easy as to say something from minds. When saying something, we can utter some sentences directly without thinking it deeply as in writing. In writing, we need to consider the coherent of the sentences. It is true that writing as a skill needs continuous process. To write something cannot be done by doing it at once only, but it needs some revision and editing process as well. Then, writing can be defined as "the manifestation of professional learning journey and it is a continuous process involving reflection, improvement, development, progress and fulfillment of various types and in varying measures" (Murray \& Moore, 2006: 5). They also believe in each process that writing contains different process and phases. Writing could be defined as an extension of grammar and therefore focuses on accuracy (Gordon, 2008). Writing is also as "primarily a convention for recording speech and reinforcing grammatical and lexical features of language" (Brown \& Abeywickrama, 2010: 259). They who are writing must be well educated since in writing it is completed by its own features and conventions.So, it is expected that the second language learner will be able to write coherent essays with artfully chosen rhetorical and discourse devices.

The writing process for students in an EFL classroom requires good attention. As in its process, writing has many purposes which should be noticed by both teachers and learners. One of the writing purpose is about expressing idea and conveying message to the readers. For this purpose, the writer should be able to express what his /her idea in mind is and also how to convey the message in order to make the reader gets the message. The ideas here should be arguable and seen as the most important aspect in writing (Ur, 1999). Besides, another opinion stated that writing has its own purposes and types and they also add that students write to accomplish a variety of purposes and use number of different genres. They argue that the purpose in writing determines the nature of writing itself. They also add that students need clear specification of the purpose in order to plan and compose a piece that responds to the task. In addition, there are another three purposes in writing. They are informative/expository writing, expressive/narrative writing, and persuasive writing. The three purposes of writing will describe the kinds of writing students do in second language classrooms. For example the students who want to write their personal experiences will be appropriate if they choose expressive/narrative writing, and so on. It is important to remember that students' writing ability may vary depending on their purposes. Therefore, students who are good at writing informative essays may not write good expressive essays (O’Malley \& Pierce, 1996).

Similarly, Ur explains some objectives of writing based on the assumption that the objective of the teaching of writing in a foreign language is to get learners to acquire the abilities and skills they need to produce. She defines two objectives of writing, first is writing as a means or as an end and writing for content and/or form. Writing as a means or as an end has three purposes such as writing as a means, for example: learners note down new vocabulary; copy out grammar rules; write out answers to reading or listening comprehension questions; do written test; writing as an end, for example: narrating a story and writing a letter; and writing as both means and end, for example: a written response to the reading of a controversial newspaper article (combines writing with reading); the writing anecdotes to illustrate the meaning of idioms (combine writing with vocabulary practice). While writing for content and/or form pay attention to the formal aspects such as neat handwriting, correct spelling and punctuation, as well as acceptable grammar and careful selection of vocabulary (Ur, 1999).

Therefore, writers should consider their goals in writing. Written work is usually done for a purpose and for a particular audience. For this reason, Nation mentions some purposes of the writer in writing their essay or paragraph. The purpose are to learn, to convey signal, to inform, to convince or to persuade, to entertain, to maintain friendly contact, to store informat ion, and to help remember information. For example, a friendly letter is written to keep a friend or relative informed of family's activity (Nations, 2009).

Teaching writing is different from the teaching of other skills. Brown compares writing to the swimming. He argues both are the same because students need media and someone who teach them those skills. According to him, practice is the best way to achieve the best skills to be advanced in writing or swimming. Above all, he explains some types of written language which are produced by EFL students. In order to teach writing skills better to the students, they need to know some types of written language and Writing Performances. Those types are indeed need for the students to do further study of English or for their 
ultimate academic/vocational goals. There are seven types of written language. The first type is permanence which implies the power of the writer which means the writer should have the power to emend, the power to clarify, and the power to withdraw. The second type says about the appropriate time given to the students that will lead them to be a good writer by developing efficient processes for achieving the final product. The next type is the distance which is the problem of the writer to anticipate their audience. Then, the orthography means that everything from simple greetings to extremely complex ideas is captured through the manipulation of a few dozen letters and other written symbols. After that, the complexity of written language is illustrated by learning how to remove redundancy, how to combine the sentences, how to make references to other elements in a text, how to create syntactic and lexical variety, and much more. Then, the vocabulary is necessary since writing places a heavier demand on vocabulary use. At last, the formality shows that ESL students have complex and difficult conventions which occur in academic writing where students have to learn how to describe, explain, compare, contrast, illustrate, defend, criticize, and argue (Brown, 2000).

Furthermore, there is an approach to Academic Writing. This subject is learned by the graduate students in the university and they face a variety of writing tasks. They provide an overview of some important characteristics of academic writing. As they have explained that academic writing is a product of many considerations such as audience, purpose, organization, style, flow, and presentation. These characteristics are approach to academic writing (Swales \& Feak, 2004). Indeed, teaching writing skills need some approaches. Thus, Lewis defines some approaches to teaching writing. Basically, the approaches are used in the first or second language classrooms, because teachers now speak of 'approaches' rather than the 'methods'. While the word 'method' sounds like a formula and the word 'approaches' suggest a broader starting points for language classrooms. She then summaries the seven approaches of teaching writing, they are focus on language structures, focus on text functions, focus on themes or topics, focus on creative expression, focus on composing processes, focus on content, and focus on genre and contexts of writing (Lewis, 2009).

In addition, to teach writing in language classroom, some principles of teaching writing should be noticed. There are some principles related to the evaluation of students' activity in teaching learning process. Those principles can also be used to evaluate a writing course or the writing section of a language course to make sure that learners are getting a good range of opportunities for learning. Those principles are ranked with the most important to the least important such as meaning-focused input, meaningfocused output, language-focused learning, and fluency development (Nations, 2009). Teaching writing in the EFL classroom context especially if the students have special condition such as a student-worker type needs various kinds of learning method. One method that is possible to be applied in the teaching is cooperative learning.

Cooperative learning (CL) is one of active learning where CL can help to increase learning effectiveness in the class. This is one of appropriate strategy to be applied in the teaching process and it is also seen as promising strategy in learning. CL also accommodates collaboration and cooperation where students are able to work together in a group. It gives chance to share the ideas and socialize to other students within the group through discussion. It is appropriate if we defined CL as a situation where learning in the class is performed by students with the same goal to work together in a group. By defining a CL based on the understanding of opinion from Johnson, Johnson and Holubec, CL is formed by small group of students who work together to maximize their learning (Gupta \& Ahuja, 2014). Students in the classroom collaborate to other students in a group with two or four students. They can practice how to negotiate, initiate the problem, construct their plan and evaluate the process of learning within their group. This CL is effective for learning together in a group as a community learning where they have responsibility to participate in a meaningful way rather than learning as individual which will create a competition with other students.

CL is based on the concept of working together to achieve learning goals that they cannot achieve it if they work individually. By understanding the opinion of Kagan, CL has various learning activities to improve students' understanding toward a subject by involving some series of steps, requiring students to create, analyze and apply concepts. In CL, each student help the other students to understand the subject. They are working together until each member in the group understand the subject and complete their assignment. This situation will create what Panitz says as atmosphere of achievement where they do not compete each other but working together to achieve their goals (Gupta \& Ahuja, 2014). By referring to this understanding of CL, students are gained many advantages in learning. Teachers or lecturers can apply various kinds of CL such as Students TeamsAchievements Divisions (STAD), Teams-Games Tournament (TGT), Jigsaw, Team Accelerated Instruction (TAI) and Cooperative Integrated Reading and Composition (CIRC).

One technique that seemed to be appropriate in EFL writing classroom context is Cooperative Integrated Reading and Composition (CIRC). By understanding the point of view from Madden, Stevens and Slavin, CIRC is developed as a schoolbased program that targets reading, writing, and language arts in grades 2 through 6 . The three principle program elements are direct instruction in reading comprehension, story-related activities, and integrated language arts/writing instruction. Each student is paired with another student and then assigned to a group of students at the same or different reading level. These learning teams work cooperatively on program-related activities. All activities follow a cycle that involves teacher presentation, team practice, peer pre-assessment, additional practice, and testing. Students are encouraged to cooperate and help one another, because students' scores on individual assessments are summed to form team scores (Durukan, 2011).

By comprehending the view from Senemolu and Slavin, CIRC technique is developed to support traditionally used skill-based reading groups approach. Firstly, reading groups are established in the classroom. Next, students are paired off within the groups. 
When the teacher or lecturer works with a reading group, couples try to teach each other meaningful reading and writing skills by using reciprocal learning technique. They help each other in performing basic skill-building activities (such as oral reading, contextual guessing, asking questions, summarizing, writing a composition based on the story, revising-correcting composition). In general, team books are published at the end of this process. Teams are rewarded for all reading and writing assignments on the basis of the average performance of group members. Thus, equal change for achievement, group support for achievement, and the performance, all basic components of cooperative learning ensure realization of personal responsibility (Durukan, 2011).

Teaching students with CIRC technique is different than teaching to the conventional teaching of writing. Teaching writing through CIRC technique involves some elements as proposed by Slavin. There are eight elements which make up the CIRC technique such as teams, placement test, student creative, team study, team scorer and recognition, teaching group, fact test, and whole-class unit. In teaching writing using CIRC technique, the students form a group consisting of four students and then the teacher or lecturer will give a material to be discussed. Next, the students read the material and work together to find the main idea of the passage in the material. After that, the students write their conclusion in a paper and deliver their conclusion in front of the class. Finally, teacher or lecturer will give the reinforcement and together with the students make the conclusion about the material given. Teacher or lecturer closes the teaching session after delivering the conclusion of the material. From the review of the theory stated by some experts, it is certainly suitable that the CIRC can be applied in the university especially if the students are the students-workers type where almost of them are full time workers.

\section{METHOD}

This research is designed with a descriptive research which involved collecting the data concerning to the current status or phenomenon. This research is analyzed by using qualitative analysis where it is aimed at describing things as the way they are (Arikunto, 2010; Gay, Mills, \& Airasian, 2009). The data is collected by using observation, field note and questionnaire. Observation is used during the teaching learning process in the class of writing subject and field note is used together with the observation where the researchers took notes from the observation done during the research. Then, questionnaire is given to the students in order to know the students' point of view toward the phenomenon being discussed. After that, the researcher describes the phenomenon based on the data found. The researcher conducted the research in UniversitasPuteraBatam where the students are mostly students-workers type.

\section{FINDING AND DISCUSSION}

The researchers conducted the research based on the experience of the teaching and learning of writing subject in UniversitasPuteraBatam. This research was conducted in academic year of 2016-2017. The researchers took the second semester where one of the researcher taught writing class. The researchers stimulated the scenario to describe the phenomenon in teaching the writing subject. The first scenario that the researchers used was the conventional teaching in the half of the semester (7 meetings from 14 meetings) to know the students' point of view about the process of teaching learning the writing subject. The rest semester used the CIRC technique where the students had collaboration to other students in a small heterogenic group to discuss about the theory or material given. During the semester, the researchers did the whole observation and field note to gain the data. After the first and the second setting ended, the researchers gave them questionnaire to be answered based on their experience through the process of learning writing subject of both setting. The informant of the questionnaire were about 31 students.

During the semester, the process of teaching and learning the writing subject was considered as fair good. Based on the average score of their daily tasks, it showed the score 70 from range 1-100. The score of their daily tasks were the accumulation from the tasks within 14 meetings. If we separated the score of their daily task into the scenario, score for the first scenario was 64.2 and the score for the second one was 75.8. In every meeting, they had practices to master this skill or in EFL context it could be said as to understand this skill better instead of 'to master'. Through practices, they learned many things to ask such the question beginning with what, where, when, why and how in their writing. They got the theory from the lecture and the lecturer guided them to write, gave a feedback, did editing and revision. The step was continuously repeated in every meeting but in the slow pace. Since these EFL students (students from UniversitasPuteraBatam) are the students-workers type where having limited time to study, limited access to the sources, and limited energy to do the task. In brief, it is a great challenge for the lecturer to bring the students into the ideal condition.

Generally the researchers found that students had some major difficulties in writing subject. From the facts that the researchers found, the major difficulties that they had such as low writing scores, bad managing of time, laziness, and some other related issues. The researchers saw these issues as the factors which made the opinion about writing. As it is believed that the writing subject is not an easy one, the fact said so. The students of EFL in Batam, especially in UniversitasPuteraBatam, were faced with their own dilemma where they have to study in the university and work in the factory at the same time. Many of them have different background of cultures, come from many regions, speak their own languages, and different education backgrounds. When they met at the campus all together, these complex background sometimes become the barrier of their learning. For example, the culture in the university demands a very high intention to learn about every subject and it is hoped that the students can be autonomous learners where they can find the information themselves. Meanwhile, many students who came from the 
district or sub-district or even categorized such a remote area, their first intention is working to support the economy of their parents and themselves as well, not studying. Thus, it is difficult for them to take a part as an ideal student condition where they have to be fit in their new university culture.

The researchers also wrote some important findings in teaching learning the writing subject in UniversitasPuteraBatam such as the process of writing subject becomes an unpleasant time where they have to write for many hours (mostly 4 sks or 200 minutes). They come to the campus mostly after working in the previous morning or night, so the rest of their energy will be used for studying the writing subject and it turns to be a very boring situation where they are very tired and sleepy. The lecturers demand them to be able to understand the instruction and follow the class during session till the end. If there is no any way to cope the problem, the students will not follow the class properly, instead they will sleep behind their friends' back.

The researchers did the observation through the whole meetings and took a field note. The researcher found some interesting facts between both scenarios, where the teaching variation by using CIRC gave a positive result than the conventional teaching. For the first setting, the researchers (one researcher is teaching and the other is observing and taking note) taught the students by using conventional teaching. Using conventional teaching means that the researchers gave the explanation about writing theory and gave motivation to write without using any specific technique. Students did their writing task alone without discussion. During the first meeting, both researchers saw that students were diligent and full of enthusiasm. The ideal condition for the students was here. But, when they got task to write, there was a little worried feeling that they could not write well because they did not master the English grammar.

Following the next meeting, some students were found sleepy because of working. They got the task as usual, then they did the task with fresh expression in the beginning and turned out to be sleepy in the middle of the process. One or two students were late coming to the class and few of them sometimes did not come to the class at all. For this one, they skipped the process of writing. Some students were able to follow the instruction and able to complete their writing task but some were still confuse and did some part of the task. There were also students who were not able to complete the writing task because they did not have much time. In this situation, students who did not complete the writing task would lost the daily score. After that, the students' writing tasks were read, corrected and given feedback by the lecturer so that students could improve their writing in the next writing task. These findings from observation and field notes of the first 7 meeting by using conventional teaching will create two kinds of student's type, a brilliant one and need study hard student. For the first type, it will not be a problem, but for the second one, lecturer should give his/her extra attention. Writing as a language skill is one skill that is assumed as the most difficult skill than the other (Mubarak, 2013; Richards \& Renandya, 2002).

For the second setting, the researchers taught the students by using CIRC technique. Firstly, the same situation happened as the previous setting where the students were diligent and full of enthusiasm after the lecturer gave the theory and motivation. After that, by applying the CIRC technique, the researchers divided students into some heterogenic group consisting of four students. The researchers gave explanation about the theory and gave a reading material. After that, students read the material together. Then, they had discussion about the reading material and worked together to get the conclusion from the reading material. Next, they discussed more about their discussion result previously and decided to write their best conclusion. Finally, they presented their writing in front of the class. Together with the lecturer they concluded the reading material given.

CIRC combines reading and composition (writing) and this technique is appropriate technique to be applied for studentsworkers type in EFL context especially in UniversitasPuteraBatam. CIRC is appropriate solution for busy students-workers because of some reasons. Firstly, the number of sleepy students were decreased drastically even they were tired. It is because they get involve in the group learning where they have to share their own opinion about their understanding through the reading. After that, CIRC also gives a chance for students to work together to solve the problem. A student who may not dare to speak in the class asking something, probably will find himself/herself active to ask other brilliant student in the group. Then, students are able to complete the writing task relatively in a short time rather than do their writing task alone. By discussing, they have many options towards the idea in their reading materials and they are able to choose one best idea that represent well the understanding of their group. It can be said that the writing quality is improved as well.

After seeing the data taken from observation and field note, the researchers provided the data from the questionnaire as well. For the questionnaire, it was taken in meeting 7 and meeting 14. Related to the last data from the questionnaire, the researchers also found some interesting facts about teaching learning the writing subject. Students' reaction to the teaching writing subject by using particular technique such as CIRC gains a very positive result where they feel that technique helps them to understand better in writing. While the conventional teaching gave only a little help for the students (especially students-workers type) to complete their writing task. The data from the questionnaire will be compared to the data from observation and field notes to see any matches between students' action (seen from observation) and students' reaction through questionnaire.

For questionnaire in the first setting, only few students agree that the conventional teaching motivated them to learn more. In this situation, students with a better understanding will be able to complete the writing task without any problem. Consider who are not, the class will be boring for them. There will be no any cooperation or even competition to be better. Moreover, as long as the motivation is not in their heart, the result of the learning result will not be high as expected. The achievement of the learning will be a problem to some students. As a result, the process of writing task will not be easy for students. These findings are also 
related to the observation explained in the previous paragraph where conventional teaching does not help much the studentsworkers type to improve better.

The other setting revealed that the use of CIRC technique is very helpful to the teaching and learning the writing subject for the students-workers type. The use of CIRC in the class after teaching them conventionally showed a difference in the improvement of the score or students' understanding. By using CIRC, students improved their learning result better than normal learning and as well as their achievement in learning writing. In this technique, students are asked to work together to solve the problem and from the cooperation it becomes a good environment to learn. Of course, this is going to make the teaching learning process easier and motivate students to improve their English skill proficiency. In this setting, the center of the learning is the students themselves. This finding is as positive as the observation finding where CIRC is considered as one helpful technique that could be adapted in the EFL context students where they are mostly students-workers type.

\section{CONCLUSION AND RECOMMENDATION}

Teaching writing in the university level will be better by using cooperative learning technique called CIRC. Students in the EFL context are motivated by the concept of working together in a group rather than individually. Students can learn from other teammates if they are not willing to ask the lecturer. They can achieve the same goals in the learning rather than compete each other. After observing the process of teaching learning in the class, the researchers come to the conclusion that CIRC technique is appropriate to be applied in the class of writing subject where the students are students-workers type. This paper could be a preliminary research to others who want to conduct a research about teaching writing. The researchers recommend that the effectiveness of using CIRC technique is further researched more comprehensively.

\section{References}

Arikunto, S. (2010). Prosedur Penelitian: Suatu Pendekatan Praktik. Jakarta: Rineka Cipta.

Brown, H. D. (2000). Teaching by Principles: An Interactive Approach to Language Pedagogy (Second Edi). San Fransisco: Pearson Education.

Brown, H. D., \& Abeywickrama, P. (2010). Language Assessment: Principles and Classroom Practices (Second Edi). San Fransisco: Pearson Education.

Coulmas, F. (2003). Writing Systems: An Introduction to their Linguistic Analysis. New York: Cambridge University Press.

Durukan, E. (2011). Effects of Cooperative Integrated Reading and Composition ( CIRC ) Technique on Reading-Writing Skills. Academic Journals: Educational Research and Reviews, 6(January), 102-109.

Felder, R. ., \& Brent, R. (2007). Cooperative Learning. In P. . Mabrouk (Ed.), Active Learning: Models from the Analytical Sciences (pp. 34-53). Washington DC: American Chemical Society.

Gay, L. ., Mills, G. E., \& Airasian, P. (2009). Educational Research: Competencies for Analysis and Applications. New Jersey: Pearson Education.

Gordon, L. (2008). Writing and Good Language Learners. In C. Griffiths (Ed.), Lessons From Good Language Learner (pp. p. 244-254). Cambridge: Cambridge University Press.

Gupta, M., \& Ahuja, J. (2014). Cooperative Integrated Reading Composition (CIRC): Impact on Reading Comprehension Achievement in English among Seventh Graders. IMPACT: International Journal of Research in Humanities, Arts and Literature (IMPACT: IJRHAL), 2(5), 37-46. Retrieved from www.impactjournals.us

Jacobs, G. M., \& Hall, S. (2002). Implementing Cooperative Learning. In J. C. Richards \& W. A. Renandya (Eds.), Methodology in Language Teaching: An Anthology of Current Practice (pp. 52-58). Cambridge: Cambridge University Press.

Lewis, M. (2009). Teaching Writing. Singapore: SEAMEO Regional Language Center.

Mubarak, Z. H. (2013). An Analysis of Students' Ability in Building Cohesion and Coherence in Argumentative Essays Written by the Fourth Year Students of English Department at University of Bengkulu. English Language Teaching, 1(3), 30-42. Retrieved from http://ejournal.unp.ac.id/index.php/elt/article/view/4592

Murray, R., \& Moore, S. (2006). The Handbook of Academic Writing: A Fresh Approach. New York: McGraw-Hill Education.

Nations, I. S. P. (2009). Teaching ESL/EFL Reading and Writing. New York: Routledge.

O'Malley, J. M., \& Pierce, L. V. (1996). Authentic Assessment for English Language Learners: Practical Approaches for Teachers. Virginia: Addison-Wesley Publishing Company.

Oshima, A., \& Hogue, A. (2009). Writing Academic English (Fourth). Upper Saddle River: Pearson Education.

Richards, J. C., \& Renandya, W. A. (2002). Introduction. In J. C. Richards \& W. A. Renandya (Eds.), Methodology in Language Teaching: An Anthology of Current Practice (pp. 303-305). New York: Cambridge University Press.

Swales, J. M., \& Feak, C. B. (2004). Academic Writing for Graduate Students: Essential Tasks and Skills. (C. G. Madden \& J. M. Swales, Eds.) (Second Edi). Ann Arbor: The University of Michigan Press.

Ur, P. (1999). A Course in Language Teaching: Practice and Theory. Cambridge: Cambridge University Press. 